Sari Pediatri, Vol. 6, No. 4, Maret 2005: 176-181

\title{
Anemia pada Penyakit Keganasan Anak
}

\author{
Nababan Rouli, Pustika Amalia
}

Anemia merupakan komplikasi yang paling sering terjadi pada penyakit keganasan. Mekanismenya sangat kompleks, yaitu anemia dapat terjadi sebagai dampak langsung dari penyakit keganasan atau akibat dari pengobatannya. Angka kejadian anemia pada pasien dengan penyakit keganasan berkisar antara 35\% hingga 95\% bergantung pada jenis penyakit keganasan dan regimen kemoterapi yang dipakai. Radioterapi dan kemoterapi seperti cisplatin, etoposid, dan kombinasi dari siklofosfamid, metotreksat dan 5-fluorourasil terbukti dapat menyebabkan anemia derajat sedang sampai berat, oleh sebab itu anemia pada pasien keganasan sangat membutuhkan penanganan yang baik karena dapat mempengaruhi proses pengobatan, dan kualitas hidup.

Kata kunci: anemia, keganasan, hemoglobin, eritropoietin, dan terapi

$\not$ emia merupakan suatu gejala yang ditandai dengan rendahnya kadar hemoglobin $(\mathrm{Hb})$ dalam darah dibandingkan dengan nilai normal pada usia tertentu. ${ }^{1,2}$ Anak yang menderita penyakit keganasan biasanya akan mengalami anemia (lebih dari $50 \%$ ) yang terjadi karena penyakit keganasannya sendiri atau disebabkan oleh terapinya. ${ }^{3-6}$

Jenis penyakit keganasan pada anak sangat berbeda bila dibandingkan dengan pada orang dewasa. Mayoritas penyakit keganasan pada orang dewasa adalah karsinoma sedangkan pada anak hampir dua pertiganya adalah leukemia, limfoma dan tumor otak. 7,8 Di Divisi Hematologi dan Onkologi Departemen Ilmu Kesehatan Anak RSCM, sejak tahun 1998-2004 telah tercatat 590 orang pasien dengan penyakit keganasan dengan tiga penyakit keganasan tersering yaitu leukemia (54\%), retinoblastoma (13\%) dan limfoma (10\%).

\footnotetext{
Alamat korespondensi:

Dr Pustika Amalia, Sp.A(K)

Divisi Hematologi-Onkologi. Departemen Ilmu Kesehatan Anak FKUIRSCM.

Jl. Salemba no. 6, Jakarta 10430.

Telepon: 021-31901170, Fax.021-3913982.
}

Dr. Nababan Rouli. PPDS Bag Anak
Anemia yang berhubungan dengan penyakit keganasan disebabkan banyak faktor dan salah satunya adalah akibat metastasis tumor ke sumsum tulang, dan bila tidak ditangani akan berdampak meningkatnya mortalitas dan efektifitas terapi. Dengan banyaknya anak dengan penyakit keganasan yang bertahan hidup dan dengan berkembangnya terapi baru, maka anemia menjadi tantangan dalam pengobatan penyakit keganasan.

Tulisan ini bertujuan untuk mengetahui besarnya angka kejadian anemia pada penyakit keganasan anak, membahas etiologi, patofisiologi, masalah yang timbul serta tata laksana sehingga hasil terapi penyakit keganasan yang diberikan menjadi optimal .

\section{Epidemiologi}

Angka kejadian anemia pada penyakit keganasan bervariasi bergantung pada jenis penyakit keganasan, stadium dan lamanya penyakit yang diderita, regimen terapi yang dipakai, dan ada tidaknya infeksi. ${ }^{9-12}$ Lebih dari lima puluh persen pasien dengan penyakit keganasan akan mengalami anemia. ${ }^{4,5}$ Penelitian di Belgia, melaporkan $79 \%$ pasien dengan penyakit keganasan mengalami anemia, dan membuktikan bahwa anemia setelah kemoterapi terjadi pada 90\% 
pasien leukemia dan 69\% pasien tumor padat. ${ }^{13}$ Sitostatik yang dapat menyebabkan anemia adalah cisplatin, karboplatin, etoposid, doxorubisin dan 5fluorourasil. ${ }^{12}$ Terapi radiasi juga dapat meningkatkan angka kejadian anemia pada penyakit keganasan, dari $48 \%$ sebelum terapi radiasi menjadi $57 \%$ sesudah terapi. ${ }^{14}$

Di Divisi Hematologi dan Onkologi Departemen Ilmu Kesehatan Anak RSCM belum ada data mengenai angka kejadian anemia pada penyakit keganasan yang dihubungkan dengan jenis penyakit keganasan, stadium penyakit, dan regimen yang dipakai. Namun dari 46 kasus penyakit keganasan yang dirawat pada periode Maret 2004 - Juni 2004 yang terdiri dari 20 orang pasien leukemia dan 26 orang pasien tumor padat, didapatkan $75 \%$ pasien leukemia dan $57 \%$ pasien tumor padat mempunyai Hb kurang dari $10 \mathrm{~g} / \mathrm{dL}$.

\section{Etiologi}

Penyebab anemia pada penyakit keganasan bersifat multifaktorial, Tabel 1 memperlihatkan beberapa etiologi anemia pada pasien dengan keganasan. ${ }^{6,11}$

Pada penyakit keganasan, anemia terjadi akibat hipoplasi sumsum tulang yang akan terlihat dari penurunan jumlah retikulosit. Nilai MCV (mean corpuscular volume) dapat digunakan untuk memperkirakan etiologi anemia. Peningkatan nilai MCV

Tabel 1. Etiologi Anemia pada Pasien Keganasan ${ }^{5}$

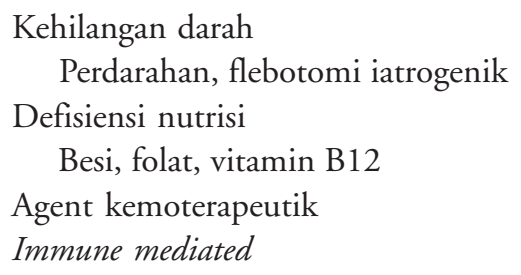

Kehilangan darah

Perdarahan, flebotomi iatrogenik

Defisiensi nutrisi

Besi, folat, vitamin B12

Agent kemoterapeutik

Immune mediated

Hemolisis, aplasia eritrosit, hemofagositosis

Metastasis sumsum tulang

Mielofibrosis

Nekrosis sumsum tulang

Hemolisis mikroangiopati

Tumor, koagulasi intravaskular diseminata, obat-

obatan

Hipersplenisme

Infeksi

Inflamasi menggambarkan suatu defisiensi nutrisi seperti vitamin B12 dan asam folat atau efek kemoterapi seperti metotreksat atau hidroksiurea. Penurunan nilai MCV umumnya menunjukkan defisiensi besi atau anemia karena keadaan inflamasi kronik. Pemeriksaan aspirasi sumsum tulang dapat membantu untuk mengevaluasi anemia dengan karena hipoplasi sumsum tulang, serta membuktikan kurangnya produksi besi atau adanya maturasi megaloblastik. Pemeriksaan ini juga dapat mengungkapkan adanya atropi lemak serous, hemofagositosis, aplasia eritrosit, mielodisplasia, limfoma, leukemia dan anemia sideroblastik. 5,12,13

\section{Patofisiologi}

Patofisiologi terjadinya anemia terbagi menjadi dua mekanisme yaitu anemia sebagai akibat efek langsung dari penyakit keganasan dan anemia sebagai akibat terapi pengobatan sitostatik dan radioterapi. ${ }^{3,4,12,15}$

\section{Anemia sebagai akibat efek langsung dari penyakit keganasan}

Patogenesis anemia penyakit (Gambar 1) merupakan interaksi antara sel tumor dengan sistem imun pejamu yang mendorong pengaturan inflamasi sitokin spesifik seperti interleukin-1 (IL-1), interferon gamma (IFN- $\gamma$ ) dan faktor nekrosis tumor (TNF$\alpha)$. Peningkatan kadar sitokin ini akan menekan progenitor eritroid burst-forming unit erythroid (BFUE) dan colony-forming unit erythroid (CFU-E) di sumsum tulang, mengganggu metabolisme besi dan mengurangi produksi eritropoietin (EPO). Kerusakan ginjal termasuk disfungsi renal oleh zat yang nefrotoksik akan menurunkan respons eritropoietin (EPO) terhadap anemia terutama saat pemberian kemoterapi. Umur eritrosit menjadi pendek sedangkan jumlah produksi sel yang baru tidak dapat mengkompensasi. Hal inilah yang akan menyebabkan anemia. Perdarahan tumor juga akan menambah berat anemia. ${ }^{11,12,16}$

Tumor padat yang bermetastasis ke sumsum tulang sering menimbulkan anemia. Metastasis merusak sel progenitor, sel-sel sumsum tulang dan menurunkan produksi faktor pertumbuhan. ${ }^{17}$ Penelitian di Korea mendapatkan penekanan sumsum tulang pada $53 \%$ pasien leukemia dan $78 \%$ pasien tumor padat. ${ }^{18}$ 


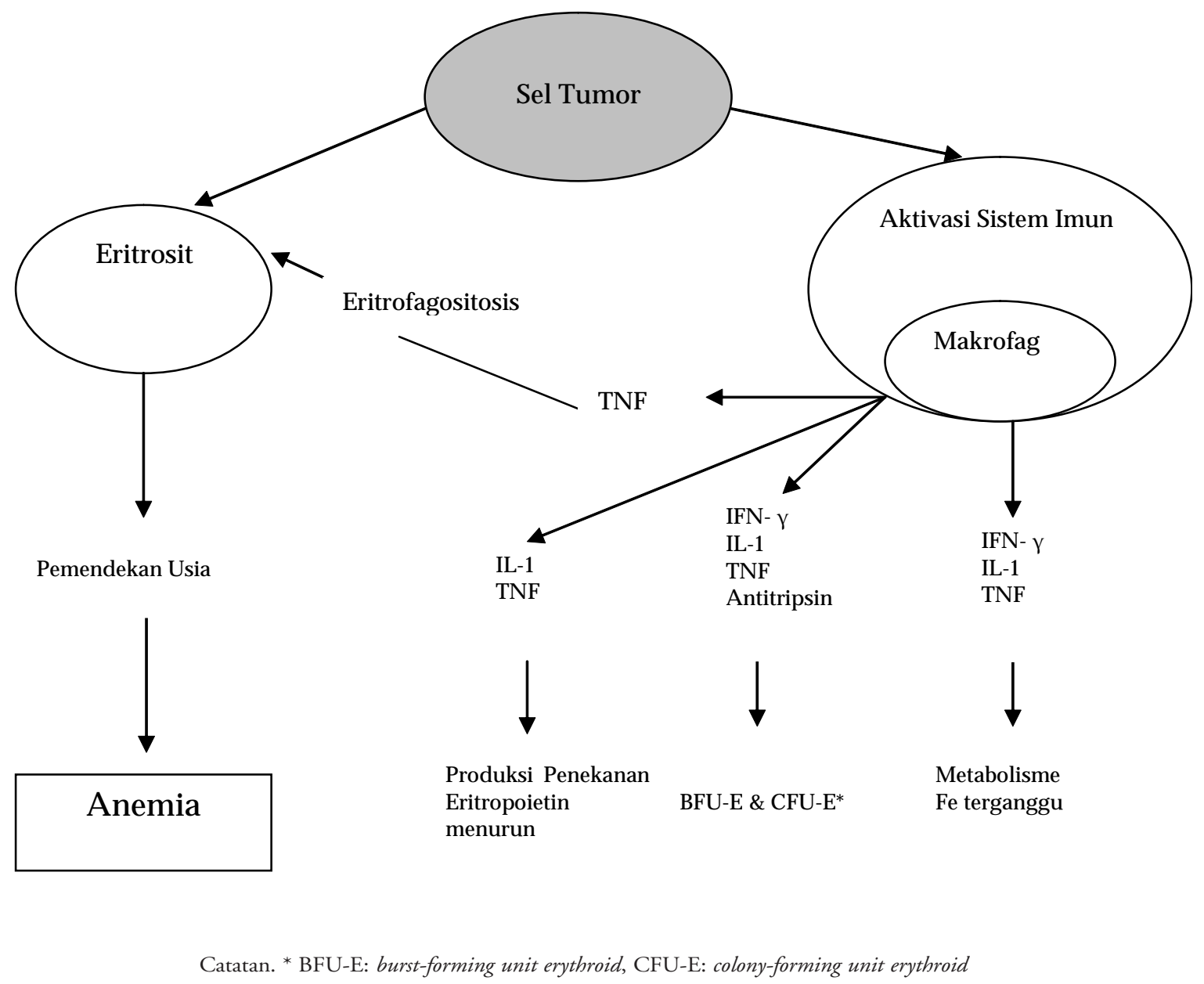

Gambar 1. Patofisiologi anemia pada penyakit keganasan. ${ }^{10}$

Beberapa jenis tumor yang bermetastasis ke sumsum tulang adalah ${ }^{19}$ histiositosis sel langerhans ( Letterer-Siwe disease), neuroblastoma, limfoma non-hodgkin, limfoma hodgkin, retinoblastoma, dan rabdomiosarkoma

\section{Anemia akibat dari terapi penyakit keganasan}

Kemoterapi atau radioterapi dapat menyebabkan terjadinya anemia dan pengulangan siklus kedua terapi ini secara kumulatif akan merusak eritropoiesis. Walaupun sebagian besar sitostatik mempunyai efek penekanan proliferasi sel pada umumnya di sumsum tulang, ada beberapa kemoterapi yang mempunyai target eritropoiesis. Sitostatik yang mengandung platinum (cisplatin dan karboplatin) merupakan penyebab tersering terjadinya komplikasi anemia sedang sampai berat, hal ini disebabkan efek toksik sitostatika tersebut pada sel renal. Cisplatin bersifat nefrotoksik terutama pada sel endotel kapiler peritubular yang menghasilkan eritropoietin. Sekitar $61 \%$ pasien yang mendapat cisplatin dan $49 \%$ yang mendapat karboplatin akan mengalami anemia. Selain itu kombinasi dari siklofosfamid, metotreksat dan 5-fluorourasil dapat merusak sel induk sehingga dapat menyebabkan terjadinya anemia sedang. ${ }^{5,20-1}$

Corazza F dari Belgia membuktikan 90\% pasien leukemia dan $69 \%$ pasien tumor ganas yang mendapat terapi cisplatin mengalami anemia. ${ }^{12} \mathrm{Hal}$ ini dapat dilihat dari kadar $\mathrm{Hb}$ sebelum tranfusi, jumlah tranfusi yang diberikan, dan turunnya kadar $\mathrm{Hb}$ per hari (Tabel 2). ${ }^{22}$ 
Sari Pediatri, Vol. 6, No. 4, Maret 2005

Tabel 2. Hubungan antara tranfusi sel darah merah dengan kemoterapi ${ }^{22}$

\begin{tabular}{lcccccc}
\hline & $\begin{array}{c}\text { Doksorubisin } \\
\mathrm{n}=14\end{array}$ & $\begin{array}{c}\text { Cisplatin } \\
\mathrm{n}=29\end{array}$ & $\begin{array}{c}\text { Etoposid } \\
\mathrm{n}=11\end{array}$ & $\begin{array}{c}5-\mathrm{FU} \\
\mathrm{n}=18\end{array}$ & $\begin{array}{c}\text { Ifosfamid } \\
\mathrm{n}=7\end{array}$ & $\begin{array}{c}\text { Total kasus } \\
\mathrm{n}=100\end{array}$ \\
\hline Kadar Hb sebelum tranfusi & 7,2 & 7,8 & 7,9 & 7,7 & 7,4 & 7,9 \\
Jumlah tranfusi & 1,6 & 2,5 & 3,1 & 2,7 & 1,4 & 2,3 \\
Total unit el darah merah & 3,3 & 5,2 & 6,9 & 6,6 & 2,6 & 5,1 \\
Batas kadar Hb & 11,7 & 11,5 & 11,3 & 11,2 & 12,7 & 11,2 \\
Turunnya kadar Hb/hari & 0,05 & 0,05 & 0,05 & 0,08 & 0,08 & 0,04 \\
Simpang baku & 3,4 & 3,9 & 6,2 & 7,4 & 3,7 & 11,3 \\
\hline
\end{tabular}

Penyakit keganasan yang mendapatkan gabungan terapi berupa radioterapi dan kemoterapi, akan meningkatkan jumlah transfusi terutama pada pasien yang mendapatkan cisplatin.

Status oksigenisasi sel berhubungan erat dengan respons radioterapi terhadap tumor. Tumor yang mengalami hipoksia memerlukan dosis radiasi 2,8-3 kali lebih besar dan bahkan dapat terjadi kegagalan radiasi dibandingkan dengan tumor dengan kadar oksigen normal. ${ }^{14,21,23}$ Kemampuan radioterapi dalam eradikasi sel ganas sangat bergantung pada kadar molekul oksigen dalam tumor, karena oksigen merupakan suatu radiosensitizer penting dalam penghancuran DNA sel ganas. Radioterapi membentuk radikal bebas dari molekul oksigen dan menerobos sampai DNA tumor sehingga menyebabkan sel tumor mati. ${ }^{14,23-5}$

Hubungan $\mathrm{Hb}$ dengan distribusi oksigen ke jaringan merupakan hal yang penting untuk menentukan hasil pengobatan penyakit keganasan, baik dengan kemoterapi atau dengan radioterapi. Penelitian di New York mendapatkan $48 \%$ pasien dengan anemia (kadar $\mathrm{Hb}<12 \mathrm{~g} / \mathrm{dL}$ ) menjadi bertambah anemi (57\%) pada akhir radioterapi. ${ }^{13,21,24}$

\section{Masalah yang timbul akibat anemia}

\section{Kelelahan dan menurunnya kualitas hidup}

Kelelahan merupakan keluhan utama pasien dengan anemia pada penyakit keganasan yang prevalensinya cukup tinggi yaitu bervariasi antara $70 \%$ sampai $90 \%$. Kelelahan mempunyai dampak yang besar pada kualitas hidup pasien, diantaranya lemah, lesu, tidak berenergi, dan kesulitan dalam memulai atau menyelesaikan pekerjaan., ${ }^{4,910,26}$

\section{Meningkatnya mortalitas}

Secara umum adanya anemia pada pasien kanker akan meningkatkan mortalitas sebanyak 65\%. Anemia pada pasien dengan karsinoma otak dan leher meningkatkan risiko mortalitas menjadi $75 \%$, sedangkan pada pasien limfoma $67 \% .{ }^{10}$

\section{Menurunkan efektifitas terapi}

Hipoksia pada tumor merupakan salah satu masalah dalam terapi keganasan, selain membuat tumor menjadi resisten terhadap radioterapi dan beberapa kemoterapi (seperti siklofosfamid dan karboplatin); hipoksia juga merangsang kinetik proliferasi, posisi siklus sel dan jumlah sel tumor yang berakumulasi pada fase $G_{0}$ (fase histopatologi) sehingga terjadi perubahan ekspresi gen ke arah perubahan proteome Perubahan ini mengatur banyaknya sel yang akan dihancurkan oleh radiasi atau kemoterapi. Bila hipoksia pada tumor tidak diperbaiki maka akan terjadi proliferasi sel yang lambat, berhentinya siklus sel dan peningkatan jumlah sel pada fase $\mathrm{G}_{0}$. Hal ini menyebabkan tumor menjadi resisten terhadap radioterapi dan kemoterapi. Selain itu , hipoksia tumor yang terus menerus akan meningkatkan progresifitas dan agresifitas penyakit keganasan melalui clonal selection dan perubahan gen. Akibatnya diferensiasi dan apoptosis sel berhenti, angiogenesis menjadi kacau, penyebaran metastasis ke locoregional meningkat yang selanjutnya akan meningkatkan resistensi terapi dan memperburuk prognosis jangka panjang. ${ }^{25-27}$ 


\section{Tata laksana anemia pada penyakit keganasan}

Terapi anemia berdasarkan etiologi akan memberikan hasil yang optimal bagi pasien. Berikut ini adalah tata laksana anemia pada penyakit keganasan berdasarkan penyebabnya.

\section{Suplementasi}

Bila ditemukan keadaan defisiensi berupa defisiensi besi, folat atau vitamin B12. maka perlu diberikan suplementasi. ${ }^{9}$ Suplemen besi dibutuhkan sebagai terapi kombinasi dengan recombinant human eritropoietin (rHuEPO) agar lebih efektif dan efisien dalam mengkoreksi $\mathrm{Hb}$. Pemberian secara oral lebih disukai walaupun menyebabkan efek samping berupa rasa mual. Pemberian secara intravena selain tidak nyaman dan mahal, juga dapat terjadi reaksi anafilaksis., ${ }^{2,10}$

\section{Transfusi eritrosit}

Transfusi eritrosit diberikan untuk memenuhi kebutuhan oksigen yaitu pada kasus anemia akut setelah perdarahan, anemia kronik yang tidak responsif dengan suplementasi besi dan pada pasien dengan anemia yang berat. Jumlah eritrosit yang dapat diberikan sebanyak 10-15 mL per kg berat badan dalam empat jam. Pada anak dengan nilai $\mathrm{Hb}<5 \mathrm{~g} /$ dL sebaiknya diberikan $4 \mathrm{~mL}$ per $\mathrm{kg}$ berat badan per kali, dalam empat jam, diselingi pemberian diuretik untuk mencegah terjadinya overload.

\section{Recombinant human eritropoietin (rHuEPO)}

Salah satu kemajuan yang sangat penting dalam terapi anemia adalah adanya rHuEPO, yang telah digunakan sejak tahun 1980. Pemberian rHuEPO dapat meningkatkan eritrosit dan nilai $\mathrm{Hb}$ sehingga dapat mengurangi pemberian transfusi darah, mengurangi gejala kelelahan dan meningkatkan kualitas hidup.,11,17 Terapi ini juga terbukti aman, efek samping minimal dan dapat ditoleransi dengan baik oleh tubuh. Sekitar $50 \%-60 \%$ pasien yang diobati dengan satu siklus pemberian $\mathrm{rHuEPO}$ dalam meningkatkan kadar $\mathrm{Hb}$ sekitar $2 \mathrm{~g} / \mathrm{dL} .^{9}$

National Comprehensive Cancer Network merekomendasikan pemberian rHuEPO pada pasien dengan kadar Hb kurang dari $11 \mathrm{~g} / \mathrm{dL}$. Sedangkan The America Society of Clinical Oncology dan The America Society of Hematology merekomendasikan pemberian rHuEPO pada pasien dengan nilai $\mathrm{Hb}=10 \mathrm{~g} / \mathrm{dL}$. Dosis $\mathrm{rHuEPO}$ yang direkomendasikan oleh ketiga institusi tersebut adalah $150 \mathrm{U} / \mathrm{kg}$ yang diberikan subkutan tiga kali seminggu, minimal selama empat minggu sebagai dosis awal. Bila dengan dosis awal tidak memberikan respon yang baik, dosis dapat ditingkatkan menjadi $300 \mathrm{U} / \mathrm{kg}$ dengan dosis maksimal $40.000 \mathrm{U} /$ minggu $^{6,28}$ yang diberikan subkutan tiga kali seminggu selama empat minggu kemudian.

Dalam sebuah penelitian meta-analisis didapatkan 22 buah randomized controlled trials (RCT) yang melaporkan adanya peningkatan rerata $\mathrm{Hb}$ dari 8,6 $\mathrm{g} / \mathrm{dL}$ menjadi 13,0 g/dL. Beberapa penelitian RCT mendapatkan hal yang sama. ${ }^{20,29,30}$

\section{Daftar Pustaka}

1. Conrad ME. Anemia. www.emedicine.com. Diakses tanggal 10 Februari 2004.

2. Abrahamian FM, Wilke E. Anemia, chronic. www.emedicine.com. Diakses tanggal 10 Februari 2004.

3. Frenkel EP, Bick RL, Rutherford CJ. Anemia of malignancy. Hematol Oncol Clin North Am 1996;10:86173.

4. Gordon MS. Managing anemia in the cancer patient: old problems, future solutions. Oncologist 2002;7:33141.

5. Moliterno AR, Spivak JL. Anemia of cancer. Hematol Oncol Clin North Am 1996;10:345-63.

6. Armstrong J, Hurria A, Hudis C. Cancer and treatmentrelated anemia: understanding and interpreting the latest anemia guidelines. www.medscape.com. Diakses tanggal 15 Februari 2004.

7. Young G, Toretsky JA, Campbell AB, Eskenazi AE. Recognition of common childhood malignancies. www.aafp.org. Diakses tanggal 1 April 2004.

8. Kupfer GM. Childhood cancer, epidemiology. www.emedicine.com. Diakses tanggal 4 Juni 2004.

9. Gillespie TW. Anemia in cancer: therapeutic implications and interventions. Cancer Nurs 2003;26(2):11928.

10. Anemia \& cancer. Dalam: Anemia a hidden epidemic. www.anemia.org. Diakses tanggal 15 Februari 2004.

11. Ludwig H. Epoetin in cancer-related anaemia. Nephrol dial transplant 1999;14(suppl 2):85-92. 
12. Corazza F, Beguin Y, Bergmann P, Andre M, Ferster A, Devalck C, dkk. Anemia in children with cancer is associated with decreases erythropoietic activity and not with adequate erythropoietin production. Blood 1998; 92:1793-8.

13. Dicato M. Anemia in cancer: some pathophysiologi aspects. Oncologist 2003; 8(suppl 1):19-21.

14. Harrison LB, Shasha D, White C, Ramdeen B. Radiotherapy-associated anemia: the scope of the problem. Oncologist 2000; 5(suppl 2):1-7.

15. Saba HI. Anemia in cancer patients: introduction and overview. www.moffitt.usf.edu/pubs/ccj/v5ns/toc.html. Diakses tanggal 15 Februari 2004.

16. Spivak JL. The physiologic basis for the pharmacologic use of recombinan erythropoietin. www.moffitt.usf.edu/pubs/ccj/ v5ns/article5.html. Diakses tanggal 15 Februari 2004.

17. Bron D, Meuleman N, Mascaux C. Biological Basis of Anemia. Semin Oncol 2001; 28(suppl 8):1-6.

18. Kim MH, Lee JH, Wu CW, Cho SW, Lee KC. Defective erythropoiesis in bone marrow is a mechanism of anemia in children with cancer. J Korean Med Sci 2002; 17:337-40.

19. Lanzkowsky P. Hematologic manifestations of systemic diseases. Dalam: Manual of pediatric hematology and oncology. Edisi kedua. New York: Churchill livingstone; 1995. h. 63-76.

20. Varan A, Buyukpamukcu M, Kutluk T, Akyuz C. Recombinant human erythropoietin treatment for chemotherapyrelated anemia in children. Pediatrics 1999; 103:1-4.

21. Ray-Coquard I, dkk. Anaemia and cancer. Elect J Oncol 2002; 1:1-16.
22. Estrin JT, Shocket L, Kregenow R, Henry DH. A retrospective review of blood transfusions in cancer patients with anemia. Oncologist 1999; 4:318-24.

23. Dunst J. The use of epoetin alfa to increase and maintain $\mathrm{Hb}$ levels during radiotherapy. Semin oncol 2001; 28(suppl 8):42-8.

24. Harrison LB, dkk. Impact of tumor hypoxia and anemia on radiation therapy outcomes. Oncologist 2002; 7:492-508.

25. Brown JM. The hypoxic cell: a target for selective cancer therapy-eighteenth Bruce F. Cain memorial award lecture. Cancer res 1999; 59:5863-70.

26. Sobrero A, Puglisi F, Guglielmi A, Belvedere O, Aprile G, Ramello M, dkk. Fatigue: a main component of anemia symptomatology. Semin oncol 2001; 28(suppl 8):15-8.

27. Vaupel P, Kelleher DK, Hockel M. Oxygenation status of malignant tumors: phatogenesis of hypoxia and significance for tumor therapy. Semin oncol 2001; 28(suppl 8):29-35.

28. National comprehensive cancer network. Cancer and treatment-related anemia. Practice guidelines in oncology-version 1. USA, 2002.

29. Seidenfeld J, Piper M, Flamm C, Hasselblad V, Armitage JO, Bennett CL, dkk. Epoetin treatment of anemia associated with cancer therapy: a systematic review and meta-analysis of controlled clinical trials. J Natl Cancer Inst 2001; 93:1204-14.

30. Abels RI, Larholt KM, Krantz KD, Bryant EC. Recombinant human erythropoietin for the treatment of the anemia of cancer. Oncologist 1996; 1:140-50. 